\title{
Looking for Hidden Enemies of Metabarcoding: Species Composition, Habitat and Management Can Strongly Influence DNA Extraction while Examining Grassland Communities
}

\author{
Anna Rucińska ${ }^{1}$, Marcin Olszak ${ }^{1,2}{ }^{\oplus}$, Sebastian Świerszcz ${ }^{1,3, *(\mathbb{D}}$, Marcin Nobis ${ }^{4,5}$, Szymon Zubek ${ }^{4}$, \\ Grzegorz Kusza ${ }^{6}$, Maja Boczkowska ${ }^{1,7}$ (1) and Arkadiusz Nowak ${ }^{1,6}$
}

1 Polish Academy of Sciences Botanical Garden, Center for Biological Diversity Conservation in Powsin, Prawdziwka 2, 02-976 Warszawa, Poland; a.rucinska@obpan.pl (A.R.); marcin.olszak@ibb.waw.pl (M.O.); m.boczkowska@ihar.edu.pl (M.B.); anowak@uni.opole.pl (A.N.)

2 Institute of Biochemistry and Biophysics, Polish Academy of Sciences, Pawińskiego 5A, 02-106 Warszawa, Poland

3 The Franciszek Górski Institute of Plant Physiology, Polish Academy of Sciences, Niezapominajek 21, 30-239 Kraków, Poland

4 Institute of Botany, Faculty of Biology, Jagiellonian University, Gronostajowa 3, 30-387 Kraków, Poland; m.nobis@uj.edu.pl (M.N.); szymon.zubek@uj.edu.pl (S.Z.)

5 Research Laboratory 'Herbarium', National Research Tomsk State University, 634050 Tomsk, Russia

6 Institute of Biology, University of Opole, Oleska 22, 45-052 Opole, Poland; kuszag@uni.opole.pl

check for

updates

Citation: Rucińska, A.; Olszak, M.; Świerszcz, S.; Nobis, M.; Zubek, S.; Kusza, G.; Boczkowska, M.; Nowak, A. Looking for Hidden Enemies of Metabarcoding: Species Composition, Habitat and Management Can Strongly Influence DNA Extraction while Examining Grassland Communities. Biomolecules 2021, 11, 318. https://doi.org/10.3390/ biom 11020318

Academic Editor: Nurhayat Tabanca

Received: 20 January 2021

Accepted: 17 February 2021

Published: 19 February 2021

Publisher's Note: MDPI stays neutral with regard to jurisdictional claims in published maps and institutional affiliations.

Copyright: (C) 2021 by the authors. Licensee MDPI, Basel, Switzerland. This article is an open access article distributed under the terms and conditions of the Creative Commons Attribution (CC BY) license (https:/ / creativecommons.org/licenses/by/ $4.0 /)$.
7 National Centre for Plant Genetic Resources, Plant Breeding and Acclimatization Institute (IHAR)-National Research Institute, Radzików, 05-870 Błonie, Poland

* Correspondence: s.swierszcz@obpan.pl

\begin{abstract}
Despite the raising preoccupation, the critical question of how the plant community is composed belowground still remains unresolved, particularly for the conservation priority types of vegetation. The usefulness of metabarcoding analysis of the belowground parts of the plant community is subjected to a considerable bias, that often impedes detection of all species in a sample due to insufficient DNA quality or quantity. In the presented study we have attempted to find environmental factors that determine the amount and quality of DNA extracted from total plant tissue from aboveand belowground samples (1000 and 10,000 $\mathrm{cm}^{2}$ ). We analyzed the influence of land use intensity, soil properties, species composition, and season on DNA extraction. The most important factors for DNA quality were vegetation type, soil conductometry (EC), and soil $\mathrm{pH}$ for the belowground samples. The species that significantly decreased the DNA quality were Calamagrostis epigejos, Coronilla varia, and Holcus lanatus. For the aboveground part of the vegetation, the season, management intensity, and certain species-with the most prominent being Centaurea rhenana and Cirsium canum-have the highest influence. Additionally, we found that sample size, soil granulation, $\mathrm{MgO}$, organic $\mathrm{C}_{2} \mathrm{~K}_{2} \mathrm{O}$, and total soil $\mathrm{N}$ content are important for DNA extraction effectiveness. Both low $\mathrm{EC}$ and $\mathrm{pH}$ reduce significantly the yield and quality of DNA. Identifying the potential inhibitors of DNA isolation and predicting difficulties of sampling the vegetation plots for metabarcoding analysis will help to optimize the universal, low-cost multi-stage DNA extraction procedure in molecular ecology studies.
\end{abstract}

Keywords: DNA quality; belowground diversity; graminoid vegetation; Central Europe; roots; DNA extraction

\section{Introduction \\ 1.1. Assessing Belowground Biodiversity}

The vegetation ecology suffers to some extent because of shortages due to observational restrictions. A critical question of how the community is structured in space and time still remains not fully resolved for the majority of ecosystems as the species data stems mainly from the above ground surveys. A great majority of research, which has focused on niche 
differentiation, biotic interactions, environmental filtering, species coexistence, functional diversity or typology of plant communities, as well as temporal and spatial changes in vegetation, or the influence of environmental variables on vegetation, considers only the aboveground components of the plant communities as a representative diversity measure e.g., [1-5]. However, in many ecosystems, particularly in stressful habitats, the absolute plant richness and majority of biomass (e.g., 50-90\% or even more) is located belowground as roots, bulbs, rhizomes, and shoot bases [6]. This is supposed to be due to persistent belowground meristems, enabling dormancy in the soil without producing aboveground shoots [7,8]. Plants can spread roots farther than shoots [9], via stolons or rhizomes [10], resulting in overlapping root systems and increased species coexistence belowground.

Understanding the community dynamics, spatial and temporal patterns of species distribution and their functional traits or predicting the response of vegetation to environmental changes requires careful examination of belowground plant components [11]. Unfortunately, studies of the belowground part of plant communities are hampered by the problem of a reliable assigning of belowground plant organs to a species. Other restrictions are: (i) seasonality of vegetation cover along with an often limited time window available to sample individuals that can be identified using particular morphological character, e.g., floral characters of plants [12,13]; (ii) the underdevelopment of species in a high competitive community; (iii) destruction of the above part of a species by animals or humans; (iv) problems with identification of cryptic species or hybrids; and (v) the so called 'bad years' when the species remains dormant underground and detection problems occur, despite thorough field investigation even for several years. Shoots may be missing in some years but present in others $[8,14]$, resulting in $>30 \%$ variation in aboveground richness among years in natural vegetation [15-18]. Recent development of metabarcoding of environmental DNA (eDNA) and community DNA with the associated cost reduction is gradually making analyses of mixed-species environmental samples more accessible [19-21].

\subsection{Metabarcoding as a Useful Tool for Identifying Belowground Species Richness}

DNA metabarcoding as the simultaneous characterization of the whole plant community is suggested as an alternative or complementary method to traditional field research aimed at biodiversity estimation [22,23]. Total DNA extracted from the living belowground plant tissues can considerably improve our understanding of the community organization, dynamics and diversity $[6,19]$. A growing number of biologists are using metabarcoding DNA for plants detection in a given environmental sample [24-26]. The internal transcribed spacer (ITS2) subunit region has been often employed for plant metabarcoding as it has potentially high resolution at the genus and species level $[26,27]$. The application of maturase $\mathrm{K}(\mathrm{matK})$ and $\mathrm{RuBisCo}(\mathrm{rbcL})$ regions is also considered for that purpose [28]. The majority of studies have been based on analysis of different regions of the chloroplast DNA, $\operatorname{trnL}(U A A)$ intron, encoded $r b c L$ gene and nuclear 16S/18S ribosomal RNA genes or 12SmtDNA to find species composition of different groups of plants in the soil ecosystem [11,19,29-32].

\subsection{Factors Affecting the Quality and Quantity of Extracted DNA (Including Environmental and Biochemical)}

DNA metabarcoding most commonly refers to DNA extracted from environmental samples [33] which further is used to assay genome regions from one or more species through molecular genetic techniques including PCR, DNA sequencing, and high-throughput sequencing to characterize organisms present in a sample. One of the crucial steps for metabarcoding analysis is the extraction of high-quality DNA in sufficient quantity [34-36]. Many plant species produce various secondary metabolites that can interfere with both the extraction of high quality DNA and subsequent PCR analyses [37]. In practice, DNA extraction protocols are very often adjusted to particular plant species or plant tissues to obtain high quality genetic material for downstream analyses [38-41]. It has proven problematic to recommend a standardized DNA extraction protocol for plants [42]. The extraction of high quality DNA from belowground plant tissues for metabarcoding analysis seems to be more challenging. Assessing the plant richness and true composition in plant communities re- 
quires extraction of total DNA from all belowground plant biomasses (roots, bulbs, rhizomes and shoot bases) obtained from soil samples to avoid under-representation or missing any species. However, 'plant community soil' contains plant-derived substances, such as humic, fulvic, and tannic acids, and thus contaminate DNA extracted from environmental samples $[43,44]$.

In this study we address the question of what are the most influential factors that determine the quantity and quality of DNA extracted from belowground plant tissues, with a special emphasis placed on the efficiency of indexed PCR dedicated for metabarcoding analysis. We sampled three types of grassland communities (wet, moderately wet, and dry), three types of management intensity within three seasons (spring, summer, and autumn). We applied combined DNA extraction methods, in terms of DNA yield and purity, followed by sets of individually indexed PCRs. Our primary hypotheses were the following: (i) the quality of extracted DNA is hampered mainly by biochemical compounds of some coexisting species; (ii) the most influential species that inhibit the isolation of DNA are rich in carbohydrates and phenolic compounds; (iii) the intensity of management also has a significant impact on the quality and quantity of extracted DNA as it is related to the compactness of soil, increased contamination and accumulation of polysaccharides in belowground organs of plants due to aboveground stress; and (iv) the soil granulometry, particularly the finest particles fraction that effectively hamper the DNA extraction as they cannot be easily removed from the samples.

\section{Materials and Methods}

\subsection{Study Area and Sampling Design}

The surveyed vegetation types are located in central part of Opole region (SW Poland) close to its capital (wet: 50.646886, 17.951331, moderately wet: 50.681413, 17.994983, dry: $50.494326,18.047414)$. Each study site was selected in quasi-homogenous stands of recognizable, different vegetation types regarding both site conditions and floristic composition. The vegetation could be classified at alliance level (wet-Calthion, moderately wetArrhenatherion, dry-Mesobromion; [45]). The meadows selected for the research differ considerably in their floristic composition. The dominant species in the peaty meadow are: Cirsium canum, C. rivulare, Lotus uliginosus, Sanguisorba officinalis, and Selinum carvifolia. The brown soil is rich in organic matter, deep and permanently wet with long standing pools and paddles. The moderately wet meadow is composed mainly by Achillea millefolium, Arrhenatherum elatius, Plantago lanceolata, Ranunculus acris, Taraxacum officinale, and Trifolium repens. The brown soil is compacted and moderately fertile with considerable sand fraction. The richest in species is dry xerothermophilous grassland (Mesobromion) on ranker, alkaline, shallow, skeletal soil. It is composed mainly of Bromus erectus, Centaurea rhenana, Festuca ovina, Lotus corniculatus, Medicago falcata, and Sanguisorba minor. All the sites were monitored over a long period and are well known in terms of species composition and management.

In each site we selected three subareas of different intensity of management (no mowing, mowing twice a year, and intensive mowing (more than 2 per year + trampling). In each subarea we selected six plots in two groups (Figure 1). In order to find the phenological deviation in the aboveground-belowground ratio, two of them were sampled in spring (early April), two in early summer (early June), and two in autumn (September). Each of the six plots were sampled two times in nested subplots to explore the influence of sample size. The size of the two subplots was assigned using the scale differentiation by one order of magnitude as is frequently used in other vegetation ecology studies, particularly in nested-plot design [46,47]. The smaller subplot has the area of $1000 \mathrm{~cm}^{2}$ and the larger $10,000 \mathrm{~cm}^{2}$ (Figure 1). As a result we obtained 108 samples of different size $\left(54 \times 1000 \mathrm{~cm}^{2}\right.$, $54 \times 10,000 \mathrm{~cm}^{2}$ ), different management intensity and disturbance (36 in low intensity, 36 in medium intensity, and 36 in high intensity), different season ( 36 for spring, 36 for summer, and 36 for autumn) and different humidity (36 in dry, 36 in moderately wet, and 36 in wet). 


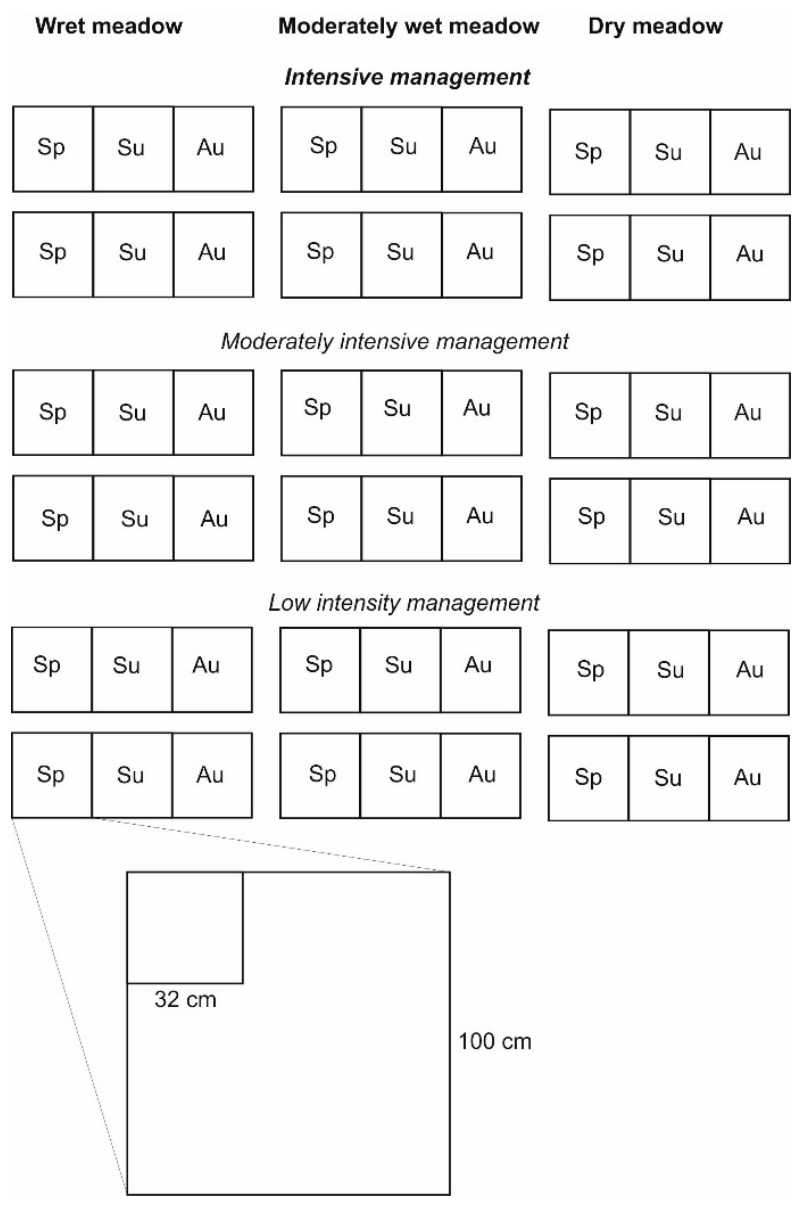

Figure 1. Sampling design. Each plot is divided into two subplots: $1 \mathrm{~m}^{2}(100 \mathrm{~cm} \times 100 \mathrm{~cm})$ and $0.1 \mathrm{~m}^{2}(32 \mathrm{~cm} \times 32 \mathrm{~cm})$. Abbreviations: $\mathrm{Sp}$-spring, $\mathrm{Su}$-summer, $\mathrm{Au}$-autumn.

\subsection{Collection of Floristic and Environmental Data}

The field studies were conducted in 2018 in grasslands in the Opole Silesia region located in the middle part of Central Europe (temperate climatic zone, circa $250 \mathrm{~m}$ above sea level, average precipitation circa $450 \mathrm{~mm} / \mathrm{y}$, average temperature circa $9^{\circ} \mathrm{C} / \mathrm{y} ;[$ [48]). The plant material was sampled from aboveground and from belowground. For each vegetation plot all the vascular plants were noted. Plant species were recorded according to the percentage cover-abundance scale. Identification and nomenclature of species were conducted according to Rutkowski [49] and Mirek et al. [50].

\subsection{Extraction, Isolation and Determination of DNA Quality and Quantity}

\subsubsection{Soil and Plant Samples for DNA Extraction}

The top $35 \mathrm{~cm}$ of soil layer was collected from two types of plots: $32 \mathrm{~cm} \times 32 \mathrm{~cm}$ $\left(1000 \mathrm{~cm}^{2}\right)$ and $100 \mathrm{~cm} \times 100 \mathrm{~cm}\left(10,000 \mathrm{~cm}^{2}\right)$. In total, 108 soil samples were collected from both types of plots which represented belowground plant tissues and, equally, 108 plant samples representing aboveground plant tissue. The soil samples were air-dried (temperature of $25^{\circ} \mathrm{C}$ ) and sieved (2-mm mesh size) before laboratory analysis. The following physico-chemical and chemical variables of soil were measured according to standard methods: $\mathrm{pH}$ in $\mathrm{H}_{2} \mathrm{O}$ and $\mathrm{KCl}$, electrical conductivity (EC), the content of total nitrogen, total and organic carbon, $\mathrm{MgO}, \mathrm{P}_{2} \mathrm{O}_{5}$, and $\mathrm{K}_{2} \mathrm{O}$ and bulk density (\%). We used a soil texture analysis kit (LaMotte Co., Chestertown, MD, USA) to estimate the proportions of sand, silt, and clay in each soil sample to find out any influence of soil features and contaminants on the quality and quantity of extracted DNA. 


\subsubsection{DNA Extraction}

DNA extraction from belowground and aboveground total biomass of each analyzed plot (Figure 1) consisted of two standard steps: (i) DNA extraction, and (ii) DNA purification. This procedure allowed us to obtain high molecular weight (HMW) DNA from all the analyzed samples suitable for metabarcoding analysis.

\section{(i) DNA extraction}

The collected and pre-purified belowground and aboveground plant material samples were crushed in the presence of liquid nitrogen and then mixed. Next, a $0.5 \mathrm{~kg}$ sample was taken and subjected to grinding in a blender with the addition of a small amount of liquid nitrogen (LN). The DNA extraction was made from $4 \mathrm{~g}$ of belowground and $3 \mathrm{~g}$ of aboveground samples of plant tissues by the CTAB-based method [51]. Each sample was mixed with $40 \mathrm{~mL}$ of CTAB buffer $(20 \mathrm{~g} \mathrm{CTAB} / \mathrm{L}, 1.4 \mathrm{M} \mathrm{NaCl}, 0.1 \mathrm{M}$ Tris-HCl, $20 \mathrm{mM}$ EDTA, $8.5 \mathrm{mM}$ sodium pyrosulphite $)$ and $10 \mu \mathrm{L}$ proteinase $\mathrm{K}(20 \mathrm{mg} / \mathrm{mL})$. The samples were incubated for $45 \mathrm{~min}$ at $65^{\circ} \mathrm{C}$ with shaking. After centrifugation, the supernatants were washed twice with chloroform:isoamyl alcohol (24:1) and treated with RNAse. DNA was precipitated using 1:1 volume of isopropanol, the pellet was washed with ethanol and resuspended in $600 \mu \mathrm{L}$ of sterile deionized water. Total DNA extracted by CTAB was still heavily contaminated, dark brown in color.

\section{(ii) DNA purification}

The DNeasy PowerSoil Kit (Qiagen, Hilden, Germany) was used according to the protocol provided by the manufacturer, including all steps with one modification - short (3 s) vortexing was used instead of bead-beating. The input sample was $200 \mu \mathrm{L}$ of contaminated DNA obtained in the previously described step. DNA was eluted column with $100 \mu \mathrm{L}$ sterile deionized water.

\subsubsection{Quantity and Quality Measurement of Plant DNA}

The quantity and purity of the extracted DNA were measured in a spectrophotometer (NanoDrop One, Thermo Fisher Scientific Inc., Wilmington, DE, USA) based on the formula: Concentration $(\mathrm{ng} / \mu \mathrm{L})=(\mathrm{OD} 260 \times 33)$. The ratios of the absorbance at $260 \mathrm{~nm}$ to 280 and $230 \mathrm{~nm}$ were used as indicators of contamination of DNA with proteins (A260/A280) and carbohydrates (A260/A230), respectively.

\subsubsection{PCR Amplification of DNA}

DNA extracted from aboveground and belowground plant tissues was submitted for PCR amplification by using an Eppendorf Thermal Cycler Mastercycler 50a, using indexed primers dedicated for Illumina MiSeq sequencing. Annealing temperature ranging from 52 to $69^{\circ} \mathrm{C}$ and denaturation temperature ranging from 93 to $99^{\circ} \mathrm{C}$ were optimized for all of primer pairs (Table S1). Amplifications of plant barcoding loci $t r n L-t r n F$ and $r b c L$ were completed using the KAPA HiFi Plant DNA polymerase (KAPA Biosystems, Roche, Pleasanton, CA, USA). All reactions were carried out in a $20 \mu \mathrm{L}$ reaction volume containing 200 ng of template DNA.

\subsection{Statistical Analysis}

The boosted regression trees (BRT) [51] were used to test the relative influence of combination of environment, soil parameters and species occurrences on plant DNA quantity and quality. Full list of predictors are presented in Table 1.

DNA quantity variable was expressed as a continuous variable. The values of DNA quality were transformed into binary values [1-DNA good quality (range of the A260-A230 absorbance ratio for proteins contamination 1.8-2.0 and range of the A260-A280 absorbance ratio for carbohydrates contamination 1.8-2.2), and 0-DNA contamination (ratio outside of the range for DNA good quality)]. We ran three different BRT models for the belowand aboveground samples. In both models we used a set of predictors that included environmental and species occurrence variables. Because the samples were collected from 
two different sized plots, we included the sample size into each model. Prior to analysis we calculated Spearman's rank correlation to detect collinearity between the soil parameters. One of each pair of highly correlated variables $(r>0.7)$ was omitted from further modeling.

Table 1. List of predictors used in this study.

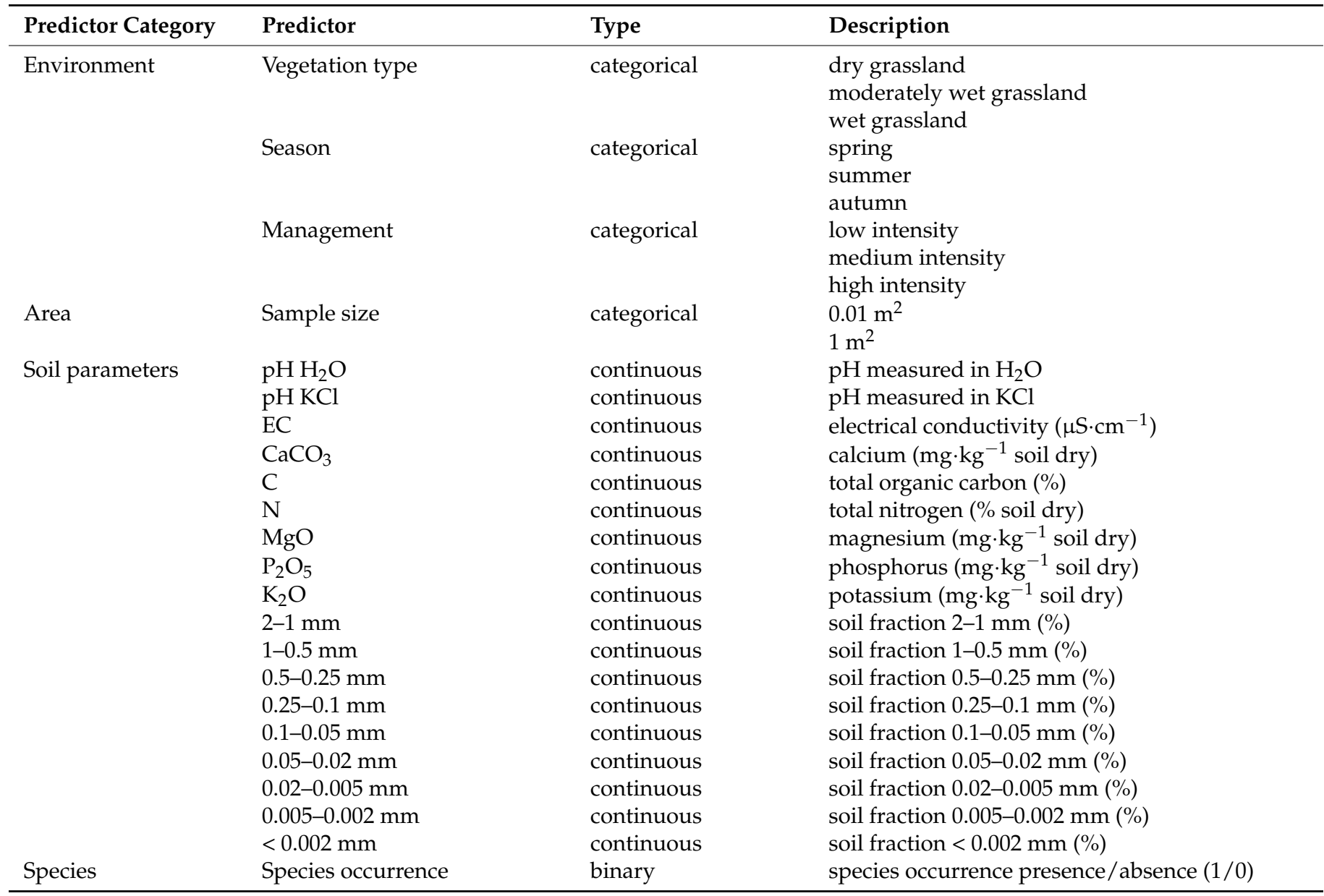

The BRT models were fitted using $g b m$ [52] and dismo [53] in R version 3.5.0 [54]. In order to calibrate the models, we first adjusted the model parameters, which included bag fraction, tree complexity $(t c)$, and learning rate $(l r)$ [51]. To determine best parametrization, we ran the model for all possible combinations of $l r=0.01,0.005,0.001,0.0005 ; \operatorname{tr}=1,2,3,4$, 5 , and default bag fraction $=0.5$. Next, we selected the combination of these parameters with the highest explained deviance based on a minimum of 1000 trees [51]. The models parameters can be found in the Supplementary Material (Table S2). Each model was simplified by reducing the number of predictors. Model performance was assessed using explained deviance values, which were between 0 and 100\% and a higher value indicates a better performance of the model.

Interpretation of the models was made by assessing relative influence and visualizing the partial dependency plots by the predictors. The relative influence of each variable is scaled so that the sum adds up to $100 \%$. Partial dependence plots were used to visualize the shape of the relationship between DNA quantity or quality and each predictor within the model [55]. Partial dependence functions show the effect of a variable on the response after accounting for the average effects of all other variables in the model [51]. All partial dependence plots for each predictor within the models are shown in the Supplementary Material (Figures S1-S6). 


\section{Results}

\subsection{Model Performance}

The higher values of deviance explained were observed for DNA quality A260-A230, both for below- and aboveground biomass ( 85.8 and $69.2 \%$, respectively), quality A260A280 for aboveground biomass (77.8\%) and DNA quantity for belowground biomass $(74 \%)$, indicating a good model performance (Figure 2). The lowest values of deviance explained were observed for DNA quality A260-A230 for belowground biomass (42.4\%) and aboveground DNA quantity (31.5\%), that indicate the influence of other variables not included in the model.

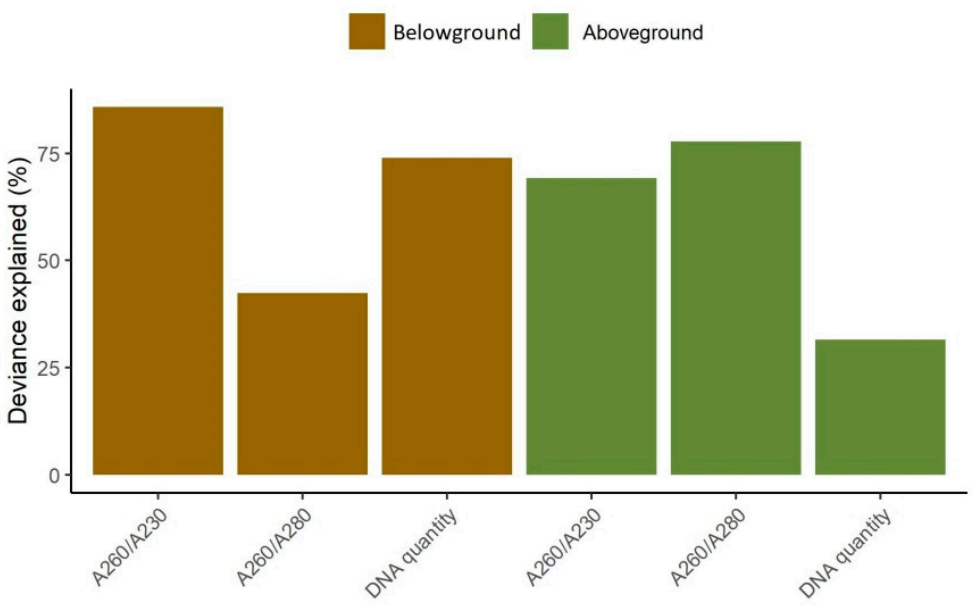

Figure 2. The explained deviance for variables representing DNA quality represented by absorbance ratios A260-A230 and A260-A280 and quantity represented by DNA concentration for belowground (brown bars) and aboveground (green bars) plant material. The values represent models after simplification.

\subsection{Factors Influencing the Extraction of DNA from Belowground Biomass}

For the ratio A260-A230, the relative influence for the predictor categories was, respectively: environment $-56.3 \%$, soil- $37.9 \%$, species $-5 \%$, and sample size $-0.8 \%$. The highest relative influence was recorded for vegetation type (55.7\%), electrical conductivity $(14.8 \%)$, and $\mathrm{pH}(6.3 \%)$ (Figure 3a). The model revealed that DNA with the lowest contamination of carbohydrates was in the belowground plant material taken from the dry and wet vegetation types, with soil electrical conductivity $>150 \mu \mathrm{S} \mathrm{cm}^{-1}$ and $\mathrm{pH}>7$ (Figure 3b).

For the ratio A260-A280, the most parsimonious model contains four predictors, with the largest relative influence recorded for soil group predictors, obtaining $90.5 \%$ in total, and for Calamagrostis epigejos from species group of predictors, obtaining $9.5 \%$ (Figure 3c). The model revealed that DNA with the lowest contamination of proteins was in belowground plant material taken from soils with electrical conductivity $>150 \mu \mathrm{S} \mathrm{cm}^{-1}$, potassium content between circa 5 and $30 \mathrm{mg} \cdot \mathrm{kg}^{-1}, \mathrm{pH}>7$ and the absence of $C$. epigejos in the vegetation (Figure 3d). For DNA concentration the largest relative influence was recorded for the group of soil predictors, which reached in total $89.6 \%$ (Figure 3e). The partial dependence plots showed that DNA concentration increased with increasing total organic carbon and phosphorus concentration and decreased with increasing $\mathrm{pH}$ and magnesium concentration in the soil (Figure 3f). 
a) Underground DNA quality A260/A230

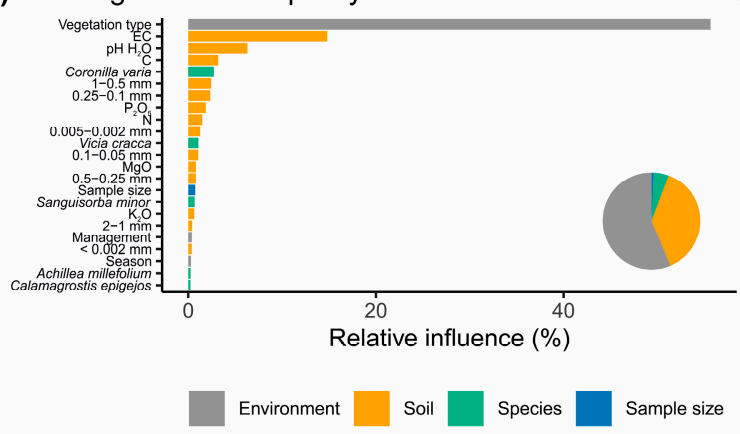

c) Underground DNA quality A260/A280

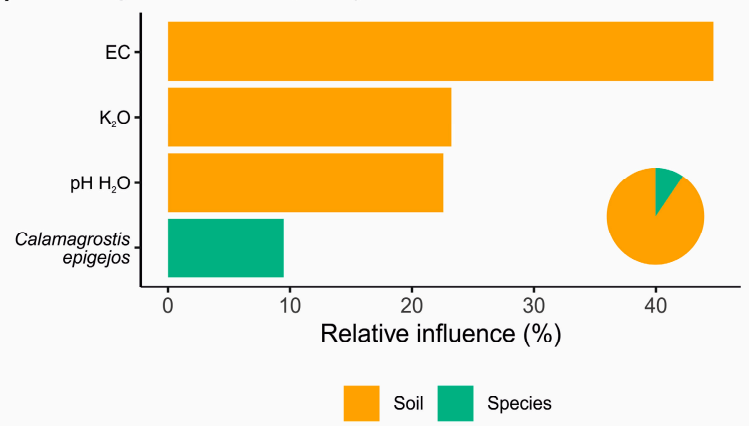

e) Underground DNA quantity

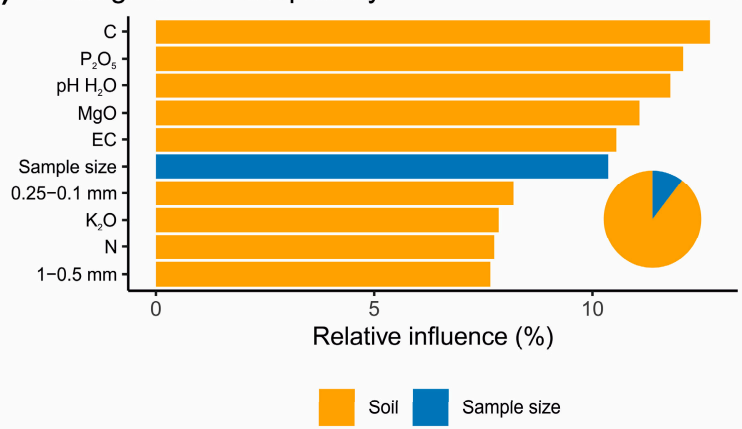

b)
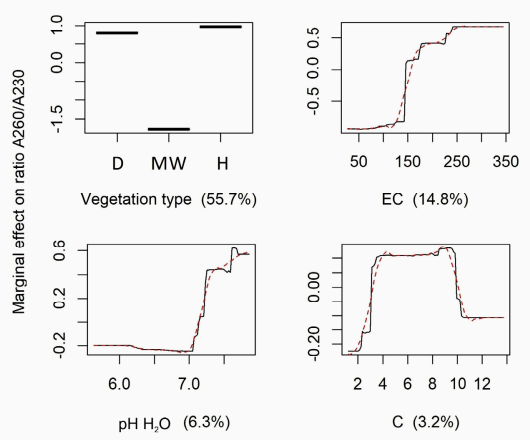

d)
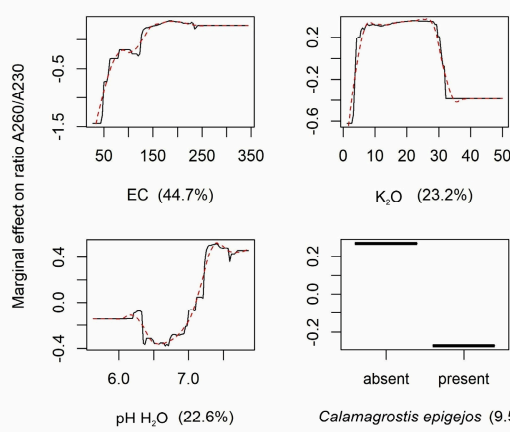

$\mathrm{K}_{2} \mathrm{O}(23.2 \%)$

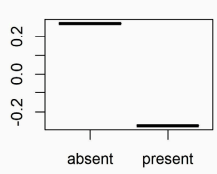

Calamagrostis epigejos $(9.5 \%$

f)

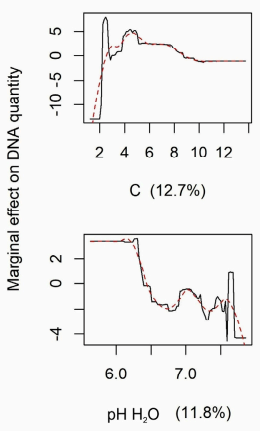

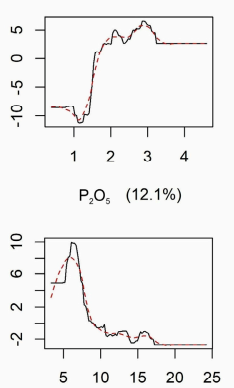

MgO (11.1\%)

Figure 3. The relative influence (\%) and main partial dependence plots showing the marginal relationships between belowground DNA quality: A260-A230 (a,b), A260-A280 (c,d), and quantity (e,f), and predictors after model simplification. Partial dependence plots show the best four predictors. Pie charts represent overall importance of the predictor categories. The full BRT models for DNA quality and quantity and all predictors are shown in Figures S1-S3. Abbreviations: D-dry grassland, MWmoderately wet grassland, $\mathrm{W}$ - wet grassland, $\mathrm{Sp}$ —spring, $\mathrm{Su}$-summer, $\mathrm{Au}$-autumn; management: L-low intensity, M-medium intensity, $\mathrm{H}$-high intensity. For more details of predictors see Table 1.

\subsection{Factors Influencing the Extraction of DNA from Aboveground Biomass}

For the ratio A260-A230, the relative influence for the predictor categories was, respectively: environment-35.1\%, species-57\%, and sample size $-7.9 \%$ (Figure $4 \mathrm{a}$ ). The model revealed that DNA with the lowest contamination detected by the $260-230$ ratio was in the aboveground plant material taken in the spring, from low managed vegetation and without Cirsium canum and Centaurea rhenana in the vegetation (Figure $4 \mathrm{~b}$ ).

For the ratio A260-A230, the relative influence for the predictor categories was, respectively: environment-27.5\%, species-64.2\%, and sample size- $8.3 \%$ (Figure $4 \mathrm{c}$ ). The model revealed that DNA with the lowest contamination was in the aboveground plant material with the absence of $C$. canum and C. rhenana, taken from wet grasslands with low management intensity (Figure 4d).

For DNA concentration the relative influence for the predictor categories was, respectively: design $-48.9 \%$, species $-34.5 \%$, and sample size $-16.5 \%$ (Figure $4 \mathrm{e}$ ). The model 
shows that the largest DNA concentration was obtained from material collected in the spring, from a larger sample size, on dry and moderately wet meadows with moderate management intensity (Figure 4f).

a) Aboveground DNA quality A260/A230

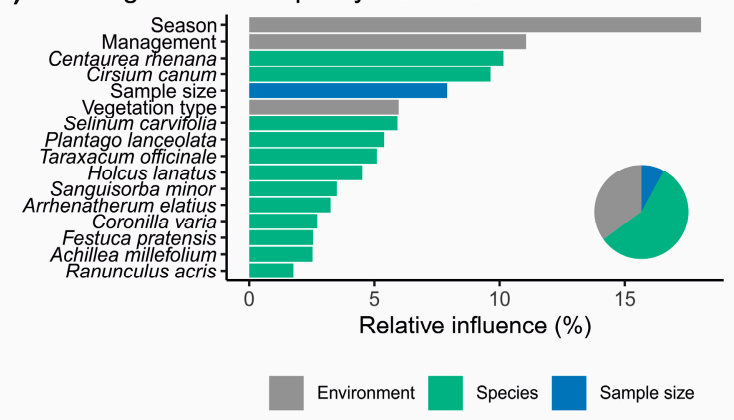

c) Aboveground DNA quality A260/A280

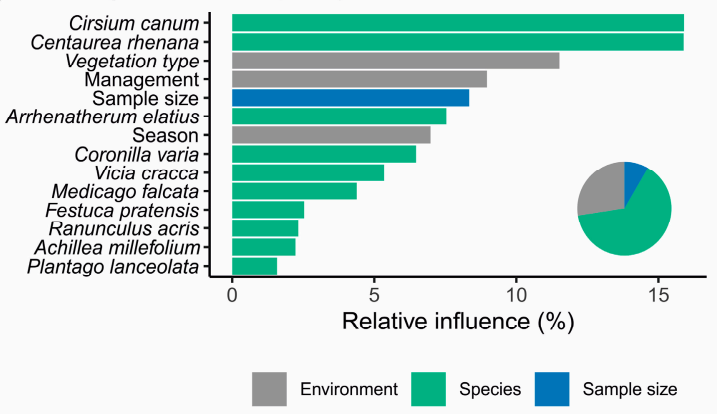

e) Aboveground DNA quantity

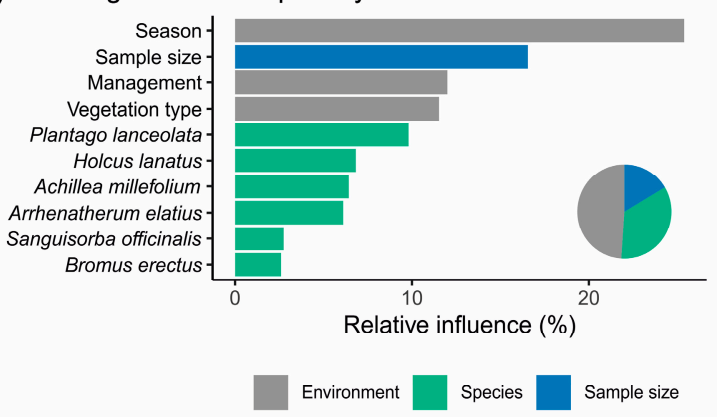

b)
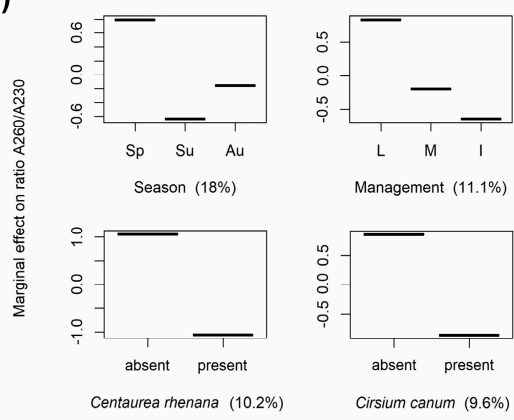

d)
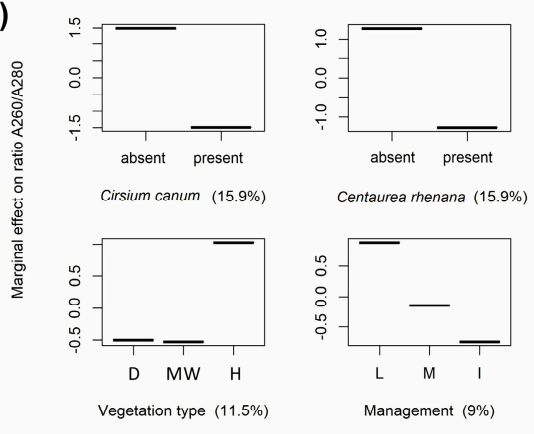

f)
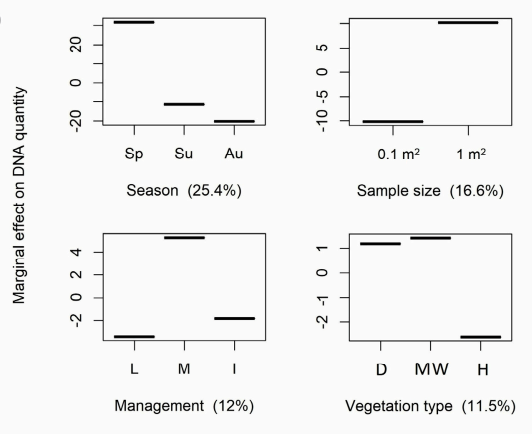

Figure 4. The relative influence (\%) and main partial dependence plots showing the marginal relationships between aboveground DNA quality: A260-A230 (a,b), A260-A280 (c,d), and quantity (e,f), and predictors after model simplification. Partial dependence plots show the best four predictors. Pie charts represent overall importance of the predictor categories. The full BRT models for DNA quality and quantity and all predictors are shown in Figures S4-S6. Abbreviations: D-dry grassland, MWmoderately wet grassland, $\mathrm{W}$-wet grassland, Sp—spring, Su—summer, Au—autumn; management: L-low intensity, M-medium intensity, $\mathrm{H}$-high intensity. For more details of predictors see Table 1.

\subsection{DNA Quality and Quantity}

PCR amplification was performed using the DNA after two-step extraction to estimate the effect of DNA extraction efficiency. The obtained results were for circa $35 \%$ samples of high quality, however for the rest they deviated from the satisfactory levels. The results of DNA quality reflected by the ratios of A260-A280 and A260-A230 for all vegetation types and seasons and the above- and belowground samples are shown in Figures 5 and 6 . 

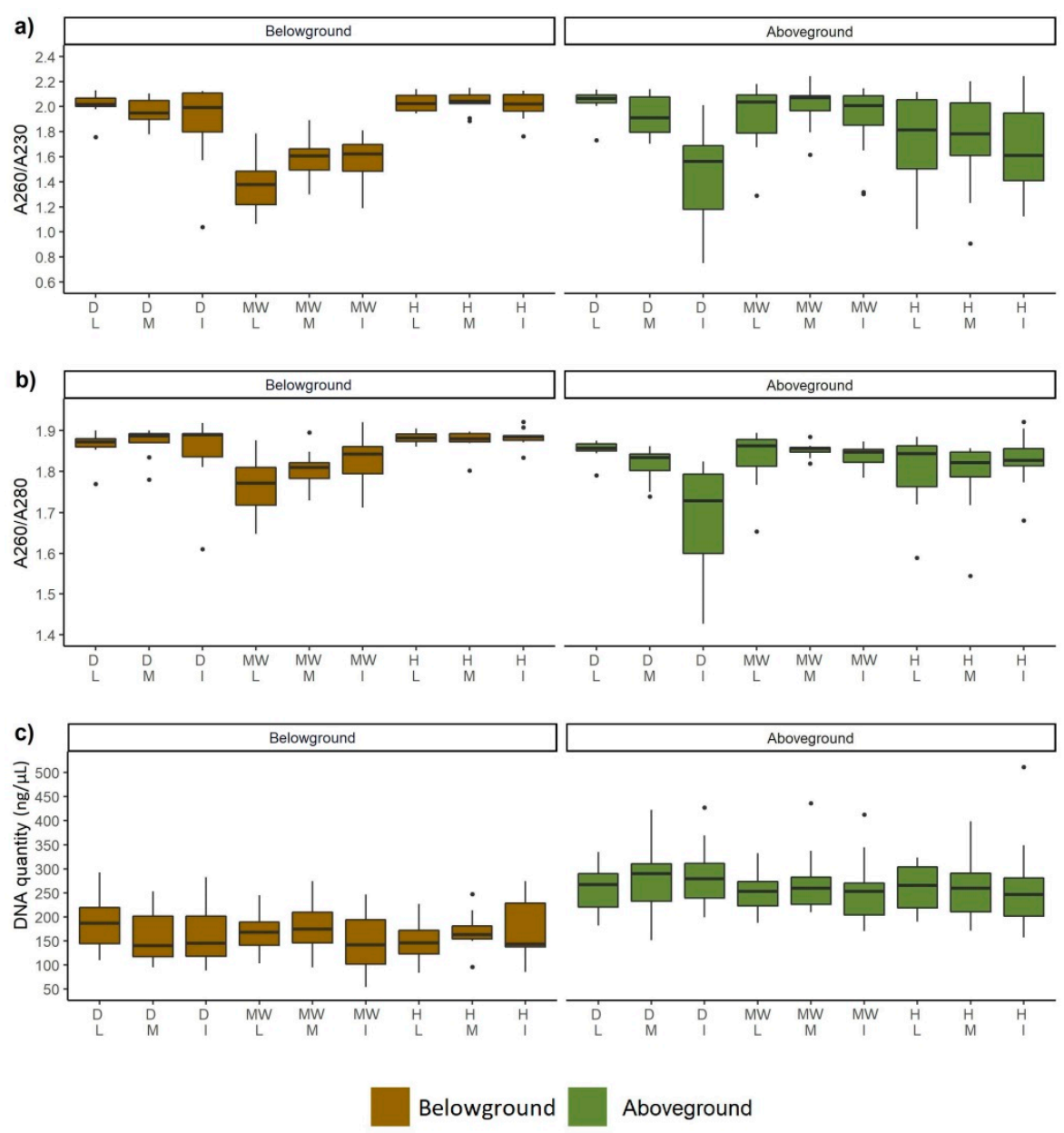

Figure 5. Comparison of quality $(\mathbf{a}, \mathbf{b})$ and yield (c) of DNA extracted from various meadow types. The horizontal line denotes the median values, the box indicates the first and third quartiles, and the points indicates outliers. For abbreviations see Figure 3.
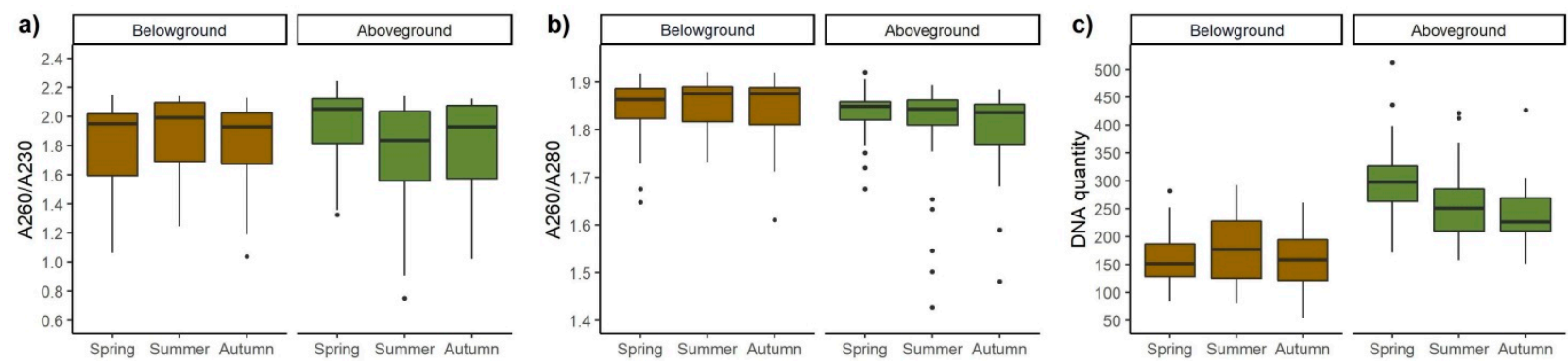

Belowground

Aboveground

Figure 6. Comparison of quality $(\mathbf{a}, \mathbf{b})$ and yield (c) of DNA extracted from various meadows sampled along vegetation season. The horizontal line denotes the median values, the box indicates the first and third quartiles, and the points indicates outliers.

The quantity of DNA isolated in different seasons ranged from 98 to $300 \mathrm{ng} / \mu \mathrm{L}$. The results of the DNA extraction showed that a higher yield of DNA was obtained from samples collected from aboveground tissues in the spring (Figure 6c). The higher amount of DNA was extracted from aboveground (Figures $5 \mathrm{c}$ and $6 \mathrm{c}$ ) than from belowground plant tissue. The best UV absorbance ratio for 260-280 and 260-230 of DNA extracted from belowground tissue was observed for wet meadows. The same ratios indicated the highest 
level of contamination in moderately wet meadows (Figure 5). The purest DNA from the aboveground tissue was from moderately wet meadows and the most contaminated from wet meadows together with dry, intensively used grassland.

\section{Discussion}

DNA metabarcoding can be applicable in ecosystem-wide studies through assessing species richness and diversity in communities over large spatial scales, though it may be hampered by a number of constraints. In order to address these constraints, we attempted to find all the influential factors in the environment, habitat, and vegetation composition that may significantly affect the quality and quantity of DNA extracted through a two-step isolation protocol.

\subsection{Plant Chemical Manufacture (Species Composition) Plays a Dominant Role in the Extraction Effectiveness}

The plant community composition was the most important factor influencing the quality and quantity of extracted DNA from belowground plant biomass (55.7\%) (Figure 3) which was derived from roots, rhizomes, bulbs, and rootstocks. Among species significantly affecting the quantity and quality of DNA, there are species with abundant root systems (e.g., Coronilla varia, Potentilla reptans, Polygonum lapathifolium, Rumex acetosa), sometimes tuberous (Cirsium canum), with thick taproots (e.g., Centaurea rhenana, Plantago lanceolata, Selinum carvifolia, Taraxacum officinale), thick rhizomes and stolons, with densely branching fibrous root system (Anthoxanthum odoratum, Festuca pratensis, Holcus lanatus, Calamagrostis epigejos) or robust rootstocks (e.g., Sanguisorba officinalis, S. minor). Such organs have a large contribution in the belowground biomass, sometimes potentially greater than their share in the aboveground biomass. Hence, as the belowground organs are often storage tissues for resources, they are a large depot for carbohydrates and other secondary metabolites that can strongly affect the DNA extraction [56].

We found that the highest amount of contaminants detected by the A260-A230 ratio concerned the moderately wet vegetation type of grassland. This acidic habitat is also poor in nitrogen, phosphorus, and total organic carbon. Other studies found high tannin concentrations in plants occurring in habitats with low soil fertility and low $\mathrm{pH}$ [57]. Thus, our observed pattern of quality DNA could also be driven by a high level of tannin in plant belowground tissue. Among the species contributing to the moderately wet community are Holcus lanatus, Rumex acetosa, Festuca rubra, Taraxacum officinale, Anthoxanthum odoratum, Cirsium arvense, Arrhenatherum elatius, and Calamagrostis epigejos. Their roots, bulb, and rootstock are known to contain many secondary compounds [58-60], thus they can potentially interfere in the DNA extraction.

Due to the fact that the community composition has a major impact on the soil habitat and the rest of the biodiversity that resides within the belowground matrix [61], the high influence of vegetation type on the quality of DNA extracted from belowground biomass is potentially involved with roots exudates and microorganisms in the vicinity of the root [62] Some species exhibit an increased amount of exudates in a specific environment. For example, low $\mathrm{pH}$ of soil can increase twice the amount of malate secreted by the roots of Holcus lanatus [63], theoretically suggesting some contribution in the lower quality of DNA from moderate wet meadow.

One of the most abundant species of moderately wet grassland was C. epigejos, whose presence in the plot is positively correlated with a high level of DNA contamination (Figure 3c). It was found that the powerful competitive ability of this species is related to the effective storage of nitrogen compounds in the roots [64]. A high content of fructans (20-25\% of dry biomass) and starch (up to 14\% of dry biomass) in rhizomes [65] suggested that these compounds could be one of the main source of contamination in DNA extract from moderately wet meadows, especially when bearing in mind the fairly high contribution of this species in many plots.

DNA obtained from plots with Coronilla varia also exhibited lower quality (Figure 3a). C. varia is a plant rich in essential oils with confirmed cytotoxic properties [66]. Such 
plants—rich in essential oils—can affect the quality and quantity of DNA isolation $[67,68]$. C. varia is also a plant rich in tannins. The condensed tannin concentration in C. varia was $16.0(\mathrm{~g} / \mathrm{kg}$ of dry weight) and it was isolated from active fractions of the crude roots extracts [69]. Interestingly, C. varia was observed only on dry meadows, suggesting the relatively strong effect of its root compounds on DNA extraction from bulked plant tissue.

\subsection{Soil Properties also Play an Important Role in the Extraction Effectiveness}

The lower quality and quantity of DNA was also influenced by the sample surface (Figure 3e). Belowground material collected from either the 1000 or $10,000 \mathrm{~cm}^{2}$ area was processed in a way that minimized the loss of species information and to avoid the underrepresentation of fine roots which make up around $90 \%$ of the root system total length [70]. Elimination of all soil particles was impossible due to the soil structure and high rooting density. Hence a relatively low yield of DNA from the $10,000 \mathrm{~cm}^{2}$ area can be attributed to higher contamination by soil particles which may have impeded the DNA extraction process. These mainly include clay parts and floated soils, sand, decaying organic matter (plant but also soil fauna), including humic substances (HS) [71].

Soil particles, together with species composition, determine the soil properties which were also very important factors for DNA purity and quantity from belowground biomass in our study (Figure 3a-f). Increases of EC $>150 \mu \mathrm{S} \cdot \mathrm{cm}^{-1}$ and $\mathrm{pH}>7$ improve the DNA quality. The highest amount of contamination was observed for moderately wet meadows. It is worth noting the multi-compound properties of lysis solution during extraction of DNA from belowground bulked plant tissue, related to both plant and soil origin. Among the soil particles HS are often described as contaminants of DNA extraction [72]. In the case of plants, the direct effects of HS on their physiology are a consequence of the flow of HS into the apoplast, the changes in proteins transport and hormone-like effects [73], therefore contamination of plant tissue with HS is unavoidable. Physicochemical analogy with the nucleic acids make them coextracted with DNA [74]. Furthermore, humic molecules can be larger than the molecular weight cutoff of centrifugal filters used in DNA purification, causing them to remain in the aqueous phase. DNA molecules could also form complexes with HS, therefore both are eluted together.

The high amount of HS in moderately wet meadow is related to the low $\mathrm{pH}$ of this habitat as stable HS occur in disrupted form in an alkaline environment, and only in acidic habitats do HS aggregate and create strong bonding [75]. Dry and wet meadows are richer in ions $\left(\mathrm{EC}>150 \mu \mathrm{S} \cdot \mathrm{cm}^{-1}\right.$ ), which can be a potential target for bonding properties of $\mathrm{HS}$. We observed in our study the positive correlation of the effectiveness of DNA extraction with the higher level of phosphate and electrolytic conductivity, of which the latter is related to the salt concentration in the soil [76]. However, the higher amount of potassium and magnesium cations negatively correlated with the yield of DNA (Figure 3e,f). Other research has shown that $\mathrm{pH}$ of the soil and the lysis buffer are potentially the most influential factors in DNA extraction from soil [77]. The results of our study confirmed that the level of $\mathrm{pH}<7$ correlates with a higher level of contamination and lower yield of DNA (Figure 3a-c).

The contamination in moderately wet meadows could also come from the adsorption of DNA on clay minerals (CM). Saeki et al. [78] have suggested that DNA adsorption on $\mathrm{CM}$ occurs via two mechanisms: direct bonding of the phosphate group at the end of the DNA molecule to the hydroxyl $(\mathrm{OH})$ groups of $\mathrm{CM}$, and the association of DNA molecules with the surface of negatively charged CM via a bridging of inorganic cations. It is also confirmed by Shen et al. [79] who proved that the presence of divalent cations $\left(\mathrm{Ca}^{2+}\right)$ in solutions greatly enhanced (even irreversibly) the adsorption of nucleic acids on CM-related particles when compared to monovalent cations $\left(\mathrm{Na}^{+}\right)$. As Saeki et al. [78] suggest, this first phenomenon is related to the assumption that inorganic anions (phosphate, selenite, and arsenate) sorb on $\mathrm{CM}$ via ligand-exchange reactions possibly occurring between the phosphate groups of the DNA molecule and the $\mathrm{OH}$ groups of the $\mathrm{CM}$ particles. In the second mechanism, DNA molecules associate with the surface of negatively charged CM via a bridging of inorganic cations, even around $\mathrm{pH} 8$. Additionally, this study indicated 
that DNA adsorption on CM decreased with increasing suspension $\mathrm{pH}$ solution, which is fully in line with our results the acidic habitat of moderately wet meadows caused the lower quality of DNA.

All the above-mentioned facts explain the high level of contamination in moderately wet meadows. The relatively low contamination effect of $\mathrm{Ca}^{2+}, \mathrm{Mg}^{2+}$, and phosphate was covered by the acidic character of the soil and thus the adsorption activity of HS and CM to DNA. The contamination effect of a high amount of $\mathrm{Ca}^{2+}$ and $\mathrm{Mg}^{2+}$ in dry meadows was partly reduced by alkaline habitat (mean 7.47) and a higher level of EC and phosphate resulting in relatively better purification of DNA.

\subsection{Aboveground, the Species Composition Is the Most Influential}

The results of the analyses showed that the presence in plots of species such as Centaurea rhenana, Cirsium canum, and others such as Selinum carvifolia, Taraxacum officinale and Holcus lanatus, was correlated with the occurrence of difficulties in DNA isolation. This may suggest a link to the chemical composition of these plants and the presence of metabolites that may undergo unpredictable biochemical transformations and strongly contaminate the DNA.

Cirsium canum and Centaurea rhenana are known to be rich in phenolic compounds [80]. C. canum contains flavonoids and phenolic acids, taraxasterol acetate, aliphatic hydrocarbons $[81,82]$, which is why the species is known to reveal strong antibacterial properties on gram-positive strains [82]. C. rhenana $(=C$. stoebe; $=$ C. maculosa $)$ is also known to have strong phytotoxic and antibacterial properties; it contains terpenoids and catechins [83-85].

An unusual response was revealed for Vicia cracca. This species inhibits the quality of the DNA only for the aboveground parts of the plant community; the belowground samples were related to the best quality DNA. The species is in fact mainly present in the aboveground biomass as the root system is not abundant, but the leaves and branching stems are quite plenteous. Regarding the plant morphology and organ architecture, a similar situation is found for Holcus lanatus that also has a detrimental effect on DNA only for the aboveground samples. This plant is known to contain a great abundance of polysaccharides, aconite acid, and aldehydes [86].

Without properly designed and conducted biochemical analyses it is difficult to indicate the most influential specific compounds. We can only—based on the biochemical profile of these species taken from literature-assume that they are able to infer the extraction procedure because of the relatively high amount of polyphenols, polysaccharides, terpenes, and their derivatives.

\subsection{Season and Stress Play an Important Role in Extraction of High Quality DNA from the Aboveground Biomass}

The two critical factors affecting the DNA isolation are the age of the plant tissue and its type (leaf, stem, etc.) [87]. It is commonly known that young and fresh plant tissues can provide DNA of the best quality and quantity due to the higher amount of young cells with less deposition of starches and secondary metabolites [88-90]. DNA from mature leaves, woody stems, etc., is of low quality and the concentrations obtained are low due to the presence of high concentrations of polyphenols, tannins, polysaccharides and other secondary metabolites that can attach strongly to DNA [87].

Seasonal patterns of carbohydrate and nutrient concentrations in the stems and leaves are well documented across many plant species. In many cases, the resorption and translocation of plant secondary metabolites can be important strategies for perennial plants to maximize resource use across multiple growing seasons [91,92]. Seasonal changes in secondary metabolite content also play a crucial role in plant defense against herbivores through toxic and feeding deterrent effects, as well as the attraction of natural enemies of herbivores [93-95]. An example is Taraxacum officinale that significantly increases secondary metabolite content and reveals strong seasonal variation in root latex chemistry [93].

The seasonality of the plant community has an apparent reflection in the condition of the plant tissue due to biological processes that are undergone during the life cycle and 
also because of the seasonal variations in habitat conditions. All these constraints make the extraction efficiency at the accepted quality from the autumn, but also some of the summer samples, scarcely achievable (Figure 4).

There is the commonly accepted view that the intensity of stress and disturbance influence the amount of secondary metabolites in plants, e.g., [96,97]. Plants have developed a variety of strategies for defending against herbivores. Among the most influential secondary metabolites, hydroxamic acids [98], tannins [99], cyanogenic glycosides [100] and alkaloids are reported, particularly in grasses that are the most important component of the meadows in our study area [96]. Another example of a reactive substance that might be involved in hampering the extraction procedure is jasmonic acid and hydrogen cyanide that are synthesized and released by plants after injury [101-103]. Additionally, terpenes and tannins and terpenoids are synthesized by the plant as a part of the defense system against herbivores $[104,105]$. The belowground part of the plant also induces the intensive production of secondary metabolites after wounding [106]. The whole plant synthesizes responsive secondary metabolites which can hinder the DNA extraction in the samples from intensively managed grasslands where the cutting and trampling was most severe.

\section{Conclusions}

Molecular ecology methods have been recognized as one of the most promising approaches in the exploration of community structure, particularly its belowground part. As we apparently evidenced, a number of environmental, ecological, and anthropogenic factors significantly influence the quality and quantity of the extracted DNA. Thus, the final results of particular study on species composition, regardless whether the below-, above-part, or the whole vegetation, can be strongly affected. Depending on the abundancy of a particular species and its chemical composition, even one species can effectively hamper the isolation of DNA. The more diverse the vegetation, the higher the risk that the sample includes the biomass impeding the procedure. Among the species that strongly correlate with highly contaminated DNA were fairly common species in Central European grasslands such as Centaurea rhenana, Cirsium canum, Taraxacum officinale, and Holcus lanatus. Additionally, the anthropogenic impact can negatively influence the acquisition of proper DNA. The plants strongly respond to intensive management and produce an array of secondary metabolites. Moreover, they can change their allocation due to frequent cutting, thus effectively hampering the extraction of DNA both in above- or belowground samples. Additionally, the sample size was of particular importance as the large ones were barely possible to be adequately cleaned.

Certainly we do not want to dissuade from applying the metabarcoding analyses when examining the real composition of the plant community. However, we believe that it is advisable to identify any potential risk factors that can spoil the results of well-designed research. We have attempted to highlight all the physico-chemical constraints and to explain the possible biochemical interactions in order to improve planning and help in avoiding the dispensable risks. Keeping in mind all the possible impediments related to the research design, species composition, environmental factors and human activity on the study area, it is workable to plan a 2-, 3- or even more step procedure of DNA extraction and to applicate additional, indispensable amendments and refinements of the isolation protocol.

Supplementary Materials: The following are available online at https:/ / www.mdpi.com/2218-273 X/11/2/318/s1, Table S1: Indexed primer sequences for each locus. Core sequences primers for $r b c L$ are from Hollingsworth et al. [107] and $t r n L-t r n F$ are from the study by Taberlet et al. [108]; Table S2: Model parameters for each DNA quality (measured as ratio A260-A230 and A260-A280) and DNA quantity (measured as DNA concentration) aboveground and belowground samples. During model calibration we tested different combinations of $l r=0.01,0.005,0.001,0.0005 ; t r=1,2,3,4,5$ and default bag fraction $=0.5$. For max trees we fixed its value in 10,000 , except in aboveground DNA concentration, where we fixed to 20,000. Model optimal parameters setting were selected based on a minimum of 1000 trees obtained [51] and the highest explained deviance; Figure S1: Partial dependence plots showing the marginal relationships of belowground DNA quality shown as ratio 
A260-A230 for all predictors of simplified BRT model; Figure S2: Partial dependence plots showing the marginal relationships of belowground DNA quality shown as ratio A260-A280 for all predictors of simplified BRT model; Figure S3: Partial dependence plots showing the marginal relationships of belowground DNA concentration for all predictors of simplified BRT model; Figure S4: Partial dependence plots showing the marginal relationships of aboveground DNA quality shown as ratio A260-A230 for all predictors of simplified BRT model; Figure S5: Partial dependence plots showing the marginal relationships of aboveground DNA quality shown as ratio A260-A280 for all predictors of simplified BRT model; Figure S6: Partial dependence plots showing the marginal relationships of aboveground DNA concentration for all predictors of simplified BRT model.

Author Contributions: Conceptualization, A.R., M.O., A.N., S.Ś; methodology, A.R., S.Ś.; software S.Ś.; validation A.N., S.Ś., M.N.; formal analysis S.Ś.; investigation S.Ś., A.N., G.K., M.N.; resources A.N., G.K.; data curation S.Ś., A.R., A.N.; writing-original draft preparation A.N., A.R., S.Ś., M.O.; writing-review and editing A.N., A.R., S.S., S.Z., M.B.; visualization S.Ś.; supervision, A.N., M.N.; project administration, A.N., A.R.; funding acquisition, A.N. All authors have read and agreed to the published version of the manuscript.

Funding: This study was partially funded by the National Science Centre, Poland, project Nos. 2017/25/B/NZ8/00572 and 2019/35/B/NZ8/03358.

Institutional Review Board Statement: Not applicable.

Informed Consent Statement: Not applicable.

Data Availability Statement: The data presented in this study are available on request from the corresponding author.

Conflicts of Interest: The authors declare no conflict of interest.

\section{References}

1. Chytrý, M.; Chiarucci, A.; Pillar, V.D.; Pärtel, M. Plant communities: Their conservation assessment and surveys across continents and in the tropics. Appl. Veg. Sci. 2015, 18,1-2. [CrossRef]

2. Dengler, J.; Boch, S. Sampling-design effects on properties of species-area relationships-A case study from Estonian dry grassland communities. Folia Geobot. 2008, 43, 289-304. [CrossRef]

3. HilleRisLambers, J.; Adler, P.B.; Harpole, W.S.; Levine, J.M.; Mayfield, M.M. Rethinking Community Assembly through the Lens of Coexistence Theory. Annu. Rev. Ecol. Evol. Syst. 2012, 43, 227-248. [CrossRef]

4. Wagner, V.; Chytrý, M.; Zelený, D.; von Wehrden, H.; Brinkert, A.; Danihelka, J.; Hölzel, N.; Jansen, F.; Kamp, J.; Lustyk, P.; et al. Regional differences in soil pH niche among dry grassland plants in Eurasia. Oikos 2017, 126, 660-670. [CrossRef]

5. Chytrý, M.; Lososová, Z.; Horsák, M.; Uher, B.; Čejka, T.; Danihelka, J.; Fajmon, K.; Hájek, O.; Juřičková, L.; Kintrová, K.; et al. Dispersal limitation is stronger in communities of microorganisms than macroorganisms across Central European cities. J. Biogeogr. 2012, 39, 1101-1111. [CrossRef]

6. Träger, S.; Öpik, M.; Vasar, M.; Wilson, S.D. Belowground plant parts are crucial for comprehensively estimating total plant richness in herbaceous and woody habitats. Ecology 2019, 100, e02575. [CrossRef] [PubMed]

7. Klimešová, J.; Klimeš, L. Bud banks and their role in vegetative regeneration-A literature review and proposal for simple classification and assessment. Perspect. Plant Ecol. Evol. Syst. 2007, 8, 115-129. [CrossRef]

8. Reintal, M.; Tali, K.; Haldna, M.; Kull, T. Habitat preferences as related to the prolonged dormancy of perennial herbs and ferns. Plant Ecol. 2010, 210, 111-123. [CrossRef]

9. Schenk, H.J.; Jackson, R.B. The global biography of roots. Ecol. Monogr. 2002, 72, 311-328. [CrossRef]

10. Zobel, M.; Moora, M.; Herben, T. Clonal mobility and its implications for spatio-temporal patterns of plant communities: What do we need to know next? Oikos 2010, 119, 802-806. [CrossRef]

11. Pärtel, M.; Hiiesalu, I.; Öpik, M.; Wilson, S.D. Below-ground plant species richness: New insights from DNA-based methods. Funct. Ecol. 2012, 26, 775-782. [CrossRef]

12. Dexter, K.G.; Pennington, T.D.; Cunningham, C.W. Using DNA to assess errors in tropical tree identifications: How often are ecologists wrong and when does it matter? Ecol. Monogr. 2010, 80, 267-286. [CrossRef]

13. Lecroq, B.; Lejzerowicz, F.; Bachar, D.; Christen, R.; Esling, P.; Baerlocher, L.; Østerås, M.; Farinelli, L.; Pawlowski, J. Ultra-deep sequencing of foraminiferal microbarcodes unveils hidden richness of early monothalamous lineages in deep-sea sediments. Proc. Natl. Acad. Sci. USA 2011, 108, 13177-13182. [CrossRef]

14. Shefferson, R.P. The evolutionary ecology of vegetative dormancy in mature herbaceous perennial plants. J. Ecol. 2009, 97, 1000-1009. [CrossRef]

15. Pärtel, M.; Zobel, M. Small-scale dynamics and species richness in successional alvar plant communities. Ecography 1995, 18, 83-90. [CrossRef] 
16. Wilson, S.D.; Tilman, D. Quadratic variation in old-field species richness along gradients of disturbance and nitrogen. Ecology 2002, 83, 492-504. [CrossRef]

17. Price, J.N.; Hiiesalu, I.; Gerhold, P.; Pärtel, M. Small-scale grassland assembly patterns differ above and below the soil surface. Ecology 2012, 93, 1290-1296. [CrossRef]

18. Wilson, S.D. Competition, resources, and vegetation during 10 years in native grassland. Ecology 2007, 88, 2951-2958. [CrossRef]

19. Hiiesalu, I.; Öpik, M.; Metsis, M.; Lilje, L.; Davison, J.; Vasar, M.; Moora, M.; Zobel, M.; Wilson, S.D.; Pärtel, M. Plant species richness belowground: Higher richness and new patterns revealed by next-generation sequencing. Mol. Ecol. 2012, 21, 2004-2016. [CrossRef]

20. Herben, T.; Suda, J.; Klimešová, J. Polyploid species rely on vegetative reproduction more than diploids: A re-examination of the old hypothesis. Ann. Bot. 2017, 120, 341-349. [CrossRef] [PubMed]

21. Li, Z.; Lamb, E.G.; Piper, C.L.; Siciliano, S.D. Plant belowground diversity and species segregation by depth in a semi-arid grassland. Ecoscience 2017, 25, 1-7. [CrossRef]

22. Parducci, L.; Matetovici, I.; Fontana, S.L.; Bennett, K.D.; Suyama, Y.; Haile, J.; Kjær, K.H.; Larsen, N.K.; Drouzas, A.D.; Willerslev, E. Molecular- and pollen-based vegetation analysis in lake sediments from central Scandinavia. Mol. Ecol. 2013, 22, 3511-3524. [CrossRef] [PubMed]

23. De Barba, M.; Miquel, C.; Boyer, F.; Mercier, C.; Rioux, D.; Coissac, E.; Taberlet, P. DNA metabarcoding multiplexing and validation of data accuracy for diet assessment: Application to omnivorous diet. Mol. Ecol. Resour. 2014, 14, 306-323. [CrossRef]

24. Alsos, I.G.; Lammers, Y.; Yoccoz, N.G.; Jørgensen, T.; Sjögren, P.; Gielly, L.; Edwards, M.E. Plant DNA metabarcoding of lake sediments: How does it represent the contemporary vegetation. PLoS ONE 2018, 13, e0195403. [CrossRef]

25. Coghlan, S.A.; Shafer, A.B.A.; Freeland, J.R. Development of an environmental DNA metabarcoding assay for aquatic vascular plant communities. Environ. DNA 2020,00,1-16. [CrossRef]

26. Banchi, E.; Ametrano, C.G.; Tordoni, E.; Stanković, D.; Ongaro, S.; Tretiach, M.; Pallavicini, A.; Muggia, L.; Verardo, P.; Tassan, F.; et al. Environmental DNA assessment of airborne plant and fungal seasonal diversity. Sci. Total Environ. 2020, 738, 140249. [CrossRef] [PubMed]

27. Cheng, T.; Xu, C.; Lei, L.; Li, C.; Zhang, Y.; Zhou, S. Barcoding the kingdom Plantae: New PCR primers for ITS regions of plants with improved universality and specificity. Mol. Ecol. Resour. 2016, 16, 138-149. [CrossRef]

28. Fahner, N.A.; Shokralla, S.; Baird, D.J.; Hajibabaei, M. Large-scale monitoring of plants through environmental DNA metabarcoding of soil: Recovery, resolution, and annotation of four DNA markers. PLoS ONE 2016, 11, 1-16. [CrossRef]

29. Soininen, E.M.; Valentini, A.; Coissac, E.; Miquel, C.; Gielly, L.; Brochmann, C.; Brysting, A.K.; Sønstebø, J.H.; Ims, R.A.; Yoccoz, N.G.; et al. Analysing diet of small herbivores: The efficiency of DNA barcoding coupled with high-throughput pyrosequencing for deciphering the composition of complex plant mixtures. Front. Zool. 2009, 6, 16. [CrossRef]

30. Pegard, A.; Miquel, C.; Valentini, A.; Coissac, E.; Bouvier, F.; François, D.; Taberlet, P.; Engel, E.; Pompanon, F. Universal DNA-based methods for assessing the diet of grazing livestock and wildlife from feces. J. Agric. Food Chem. 2009, 57, 5700-5706. [CrossRef] [PubMed]

31. Valentini, A.; Miquel, C.; Nawaz, M.A.; Bellemain, E.; Coissac, E.; Pompanon, F.; Gielly, L.; Cruaud, C.; Nascetti, G.; Wincker, P.; et al. New perspectives in diet analysis based on DNA barcoding and parallel pyrosequencing: The trnL approach. Mol. Ecol. Resour. 2009, 9, 51-60. [CrossRef] [PubMed]

32. Sønstebø, J.H.; Gielly, L.; Brysting, A.K.; Elven, R.; Edwards, M.; Haile, J.; Willerslev, E.; Coissac, E.; Rioux, D.; Sannier, J.; et al. Using next-generation sequencing for molecular reconstruction of past Arctic vegetation and climate. Mol. Ecol. Resour. 2010, 10, 1009-1018. [CrossRef]

33. Taberlet, P.; Coissac, E.; Hajibabaei, M.; Rieseberg, L.H. Environmental DNA. Mol. Ecol. 2012, 21, 1789-1793. [CrossRef] [PubMed]

34. Bertrand, H.; Poly, F.; Van, V.T.; Lombard, N.; Nalin, R.; Vogel, T.M.; Simonet, P. High molecular weight DNA recovery from soils prerequisite for biotechnological metagenomic library construction. J. Microbiol. Methods 2005, 62, 1-11. [CrossRef]

35. Lakay, F.M.; Botha, A.; Prior, B.A. Comparative analysis of environmental DNA extraction and purification methods from different humic acid-rich soils. J. Appl. Microbiol. 2007, 102, 265-273. [CrossRef] [PubMed]

36. Delmont, T.O.; Robe, P.; Clark, I.; Simonet, P.; Vogel, T.M. Metagenomic comparison of direct and indirect soil DNA extraction approaches. J. Microbiol. Methods 2011, 86, 397-400. [CrossRef]

37. Kotchoni, S.O.; Gachomo, E.W.; Jimenez-Lopez, J.C. A plant cocktail amenable for PCR-based genetic analysis in Arabidopsis thaliana. Mol. Biol. Rep. 2011, 38, 5281-5284. [CrossRef]

38. Sharma, A.D.; Gill, P.K.; Singh, P. DNA isolation from dry and fresh samples of polysaccharide-rich plants. Plant Mol. Biol. Report. 2002, 20, 415a-415f. [CrossRef]

39. Shepherd, L.D.; McLay, T.G.B. Two micro-scale protocols for the isolation of DNA from polysaccharide-rich plant tissue. J. Plant Res. 2011, 124, 311-314. [CrossRef] [PubMed]

40. Afshar-Mohammadian, M.; Rezadoost, M.H.; Fallah, S.F. Comparative analysis and innovation of a simple and rapid method for high-quality RNA and DNA extraction of kiwifruit. MethodsX 2018, 5, 352-361. [CrossRef] [PubMed]

41. Arruda, S.R.; Pereira, D.G.; Silva-Castro, M.M.; Brito, M.G.; Waldschmidt, A.M. An optimized protocol for DNA extraction in plants with a high content of secondary metabolites, based on leaves of Mimosa tenuiflora (Willd.) Poir. (Leguminosae). Genet. Mol. Res. 2017, 16, gmr16039063. [CrossRef] 
42. Lear, G.; Dickie, I.; Banks, J.; Boyer, S.; Buckley, H.; Buckley, T.; Cruickshank, R.; Dopheide, A.; Handley, K.; Hermans, S.; et al. Methods for the extraction, storage, amplification and sequencing of DNA from environmental samples. N. Z. J. Ecol. 2018, 42, 10. [CrossRef]

43. Kreader, C.A. Relief of amplification inhibition in PCR with bovine serum albumin or T4 gene 32 protein. Appl. Environ. Microbiol. 1996, 62, 1102-1106. [CrossRef]

44. Schrader, C.; Schielke, A.; Ellerbroek, L.; Johne, R. PCR inhibitors-Occurrence, properties and removal. J. Appl. Microbiol. 2012, 113, 1014-1026. [CrossRef]

45. Nowak, A.; Spałek, K. Ochrona szaty roślinnej Śląska Opolskiego; Wydawnictwo Uniwersytetu Opolskiego: Opole, Poland, 2004; p. 391.

46. Jürgens, N.; Schmiedel, U.; Haarmeyer, D.H.; Dengler, J.; Finckh, M.; Goetze, D.; Gröngröft, A.; Hahn, K.; Koulibaly, A.; LutherMosebach, J.; et al. The BIOTA Biodiversity Observatories in Africa-a standardized framework for large-scale environmental monitoring. Environ. Monit. Assess. 2012, 184, 655-678. [CrossRef] [PubMed]

47. Dengler, J. A flexible multi-scale approach for standardised recording of plant species richness patterns. Ecol. Indic. 2009, 9, 1169-1178. [CrossRef]

48. Woś, A. Klimat Polski; Wydawnictwo Naukowe PWN: Warszawa, Poland, 1999; p. 301.

49. Rutkowski, L. Klucz do oznaczania roślin naczyniowych Polski niżowej; Wydawnictwo Naukowe PWN: Warszawa, Poland, 2007; p. 814.

50. Mirek, Z.; Piękoś-Mirkowa, H.; Zając, A.; Zając, M. Flowering plants and pteridiophytes in Poland. A Checklist. Biodiversity of Poland. Vol. 1; Instytut Botaniki im. W. Szafera, PAN: Kraków, Poland, 2002; p. 440.

51. Elith, J.; Leathwick, J.R.; Hastie, T. A working guide to boosted regression trees. J. Anim. Ecol. 2008, 77, 802-813. [CrossRef] [PubMed]

52. Greenwell, B.; Boehmke, B.; Cunningham, J. GBM Developers gbm: Generalized Boosted Regression Models. R Package Version 2.1.5. 2019. Available online: https://www.researchgate.net/publication/240311335_Gbm_Generalized_Boosted_Regression_ Models_R_Package_15 (accessed on 18 February 2021).

53. Hijmans, R.J.; Phillips, S.; Leathwick, J.; Elith, J. dismo: Species Distribution Modeling. R package version 1.1-4. 2017. Available online: http:/ / www2.uaem.mx/r-mirror/web/packages/dismo/vignettes/sdm.pdf (accessed on 18 February 2021).

54. R Core Team R: A Language and Environment for Statistical Computing. 2020. Available online: http://softlibre.unizar.es/ manuales/aplicaciones/r/fullrefman.pdf (accessed on 18 February 2021).

55. Hastie, T.; Tibshirani, R.; Friedman, J. The Elements of Statistical Learning. Data Mining, Inference, and Prediction, 2nd ed.; Springer: New York, NY, USA, 2009.

56. Lucas, M.S.; Carvalho, C.S.; Hypolito, G.B.; Côrtes, M.C. Optimized protocol to isolate high quality genomic DNA from different tissues of a palm species. Hoehnea 2019, 46, e942018. [CrossRef]

57. Northup, R.R.; Dahlgren, R.A.; McColl, J.G. Polyphenols as regulators of plant-litter-soil interactions in northern California's pygmy forest: A positive feedback? Biogeochemistry 1998, 42, 189-220. [CrossRef]

58. Tiley, G.E.D. Biological Flora of the British Isles: Cirsium arvense (L.) Scop. J. Ecol. 2010, 98, 938-983. [CrossRef]

59. Tolrà, R.P.; Poschenrieder, C.; Luppi, B.; Barceló, J. Aluminium-induced changes in the profiles of both organic acids and phenolic substances underlie Al tolerance in Rumex acetosa L. Environ. Exp. Bot. 2005, 54, 231-238. [CrossRef]

60. Díaz, K.; Espinoza, L.; Madrid, A.; Pizarro, L.; Chamy, R. Isolation and identification of compounds from bioactive extracts of Taraxacum officinale Weber ex F. H. Wigg. (Dandelion) as a potential source of antibacterial agents. Evidence-based Complement. Altern. Med. 2018, 2018, 2706417.

61. Bar-On, Y.M.; Phillips, R.; Milo, R. The biomass distribution on Earth. Proc. Natl. Acad. Sci. USA 2018, 115, 6506-6511. [CrossRef]

62. Somers, E.; Vanderleyden, J.; Srinivasan, M. Rhizosphere bacterial signalling: A love parade beneath our feet. Crit. Rev. Microbiol. 2004, 30, 205-240. [CrossRef] [PubMed]

63. Chen, Z.C.; Yokosho, K.; Kashino, M.; Zhao, F.J.; Yamaji, N.; Ma, J.F. Adaptation to acidic soil is achieved by increased numbers of cis-acting elements regulating ALMT1 expression in Holcus lanatus. Plant J. 2013, 76, 10-23.

64. Gloser, V. Seasonal changes of nitrogen storage compounds in a rhizomatous grass Calamagrostis epigeios. Biol. Plant. 2002, 45, 563-568. [CrossRef]

65. Dušek, J. Seasonal dynamic of nonstructutral saccharides in a rhizomatous grass Calamagrostis epigeios. Biol. Plant. 2002, $45,383-387$. [CrossRef]

66. Dehpour, A.A.; Eslami, B.; Rezaie, S.; Hashemian, S.F.; Shafie, F.; Kiaie, M. Chemical composition of essential oil and in vitro antibacterial and anticancer activity of the hydroalcolic extract from Coronilla varia. Int. J. Biol. Biomol. Agric. Food Biotechnol. Eng. 2014, 8, 1414-1417.

67. Matasyoh, L.G.; Wachira, F.N.; Kinyua, M.G.; Thairu Muigai, A.W.; Mukiama, T.K. Leaf storage conditions and genomic DNA isolation efficiency in Ocimum gratissimum L. from Kenya. Afr. J. Biotechnol. 2008, 7, 557-564.

68. Khanuja, S.; Shasany, A.; Darokar, M.P.; Kumar, S. Rapid Isolation of DNA from Dry and Fresh Samples of Plants Producing Large Amounts of Secondary Metabolites and Essential Oils. Plant Mol. Biol. Report. 1999, 17, 74. [CrossRef]

69. Al-Snafi, A.E. The pharmacological and toxicological effects of Coronilla varia and Coronilla scorpioides: A review. Pharm. Chem. J. 2016, 3, 105-114.

70. Pierret, A.; Moran, C.J.; Doussan, C. Conventional detection methodology is limiting our ability to understand the roles and functions of fine roots. New Phytol. 2005, 166, 967-980. [CrossRef] [PubMed] 
71. Schulten, H.R.; Leinweber, P. Characterization of humic and soil particles by analytical pyrolysis and computer modeling. J. Anal. Appl. Pyrolysis 1996, 38, 1-53. [CrossRef]

72. Chiodi, C.; Moro, M.; Squartini, A.; Concheri, G.; Occhi, F.; Fornasier, F.; Cagnin, M.; Bertoldo, G.; Broccanello, C.; Stevanato, P. High-Throughput Isolation of Nucleic Acids from Soil. Soil Syst. 2019, 4, 3. [CrossRef]

73. Nardi, S.; Pizzeghello, D.; Muscolo, A.; Vianello, A. Physiological effects of humic substances on higher plants. Soil Biol. Biochem. 2002, 34, 1527-1536. [CrossRef]

74. Zhou, J.; Bruns, M.A.; Tiedje, J.M. DNA recovery from soils of diverse composition. Appl. Environ. Microbiol. 1996, 62, 316-322. [CrossRef]

75. Trevisan, S.; Francioso, O.; Quaggiotti, S.; Nardi, S. Humic substances biological activity at the plant-soil interface: From environmental aspects to molecular factors. Plant Signal. Behav. 2010, 5, 635-643. [CrossRef] [PubMed]

76. Corwin, D.L.; Lesch, S.M. Apparent soil electrical conductivity measurements in agriculture. Comput. Electron. Agric. 2005, 46, 11-43. [CrossRef]

77. Hebda, L.M.; Foran, D.R. Assessing the utility of soil DNA extraction kits for increasing DNA yields and eliminating PCR inhibitors from buried skeletal remains. J. Forensic Sci. 2015, 60, 1322-1330. [CrossRef]

78. Saeki, K.; Sakai, M.; Wada, S.I. DNA adsorption on synthetic and natural allophanes. Appl. Clay Sci. 2010, 50, 493-497. [CrossRef]

79. Shen, Y.; Kim, H.; Tong, M.; Li, Q. Influence of solution chemistry on the deposition and detachment kinetics of RNA on silica surfaces. Colloids Surfaces B Biointerfaces 2011, 82, 443-449. [CrossRef]

80. Kasterova, E.; Zibareva, L.; Revushkin, A. Secondary metabolites of some Siberian species of plants tribe Cynareae (Asteraceae). S. Afr. J. Bot. 2019, 125, 24-29. [CrossRef]

81. Jordon-Thaden, I.E.; Louda, S.M. Chemistry of Cirsium and Carduus: A role in ecological risk assessment for biological control of weeds? Biochem. Syst. Ecol. 2003, 31, 1353-1396. [CrossRef]

82. Kozyra, M.; Biernasiuk, A.; Malm, A.; Chowaniec, M. Chemical compositions and antibacterial activity of extracts obtained from the inflorescences of Cirsium canum (L.) all. Nat. Prod. Res. 2015, 29, 2059-2063. [CrossRef]

83. Olson, B.E.; Kelsey, R.G. Effect of Centaurea maculosa on sheep rumen microbial activity and mass in vitro. J. Chem. Ecol. 1997, 23, 1131-1144. [CrossRef]

84. Tharayil, N. To survive or to slay: Resource-foraging role of metabolites implicated in allelopathy. Plant Signal. Behav. 2009, 4, 580-583. [CrossRef] [PubMed]

85. Gfeller, V.; Huber, M.; Förster, C.; Huang, W.; Köllner, T.G.; Erb, M. Root volatiles in plant-plant interactions I: High root sesquiterpene release is associated with increased germination and growth of plant neighbours. Plant Cell Environ. 2019, 42, 1950-1963. [CrossRef]

86. Molloy, L.F.; Richards, E.L. Complexing of calcium and magnesium by the organic constituents of yorkshire fog (Holcus lanatus): I-The organic acids, lignin and cell wall polysaccharides of Yorkshire Fog. J. Sci. Food Agric. 1971, 22, 393-396. [CrossRef]

87. Varma, A.; Padh, H.; Shrivastava, N. Plant genomic DNA isolation: An art or a science. Biotechnol. J. 2007, 2, 386-392. [CrossRef] [PubMed]

88. Murray, M.G.; Thompson, W.F. Rapid isolation of high molecular weight plant DNA. Nucleic Acids Res. 1980, 8, 4321-4326. [CrossRef]

89. Doyle, J.J.; Doyle, J.L. A rapid DNA isolation procedure for small quantities of fresh leaf tissue. Phytochem. Bull. 1987, 19, 11-15.

90. Williams, C.E.; Ronald, P.C. PCR template-DNA isolated quickly from monocot and dicot leaves without tissue homogenization. Nucleic Acids Res. 1994, 22, 1917-1918. [CrossRef] [PubMed]

91. Freschet, G.T.; Roumet, C. Sampling roots to capture plant and soil functions. Funct. Ecol. 2017, 31, 1506-1518. [CrossRef]

92. Dietze, M.C.; Sala, A.; Carbone, M.S.; Czimczik, C.I.; Mantooth, J.A.; Richardson, A.D.; Vargas, R. Nonstructural carbon in woody plants. Annu. Rev. Plant Biol. 2014, 65, 667-687. [CrossRef]

93. Huang, W.; Bont, Z.; Hervé, M.R.; Robert, C.A.M.; Erb, M. Impact of seasonal and temperature-dependent variation in root defense metabolites on herbivore preference in Taraxacum officinale. J. Chem. Ecol. 2020, 46, 63-75. [CrossRef] [PubMed]

94. Mithöfer, A.; Boland, W. Plant Defense Against Herbivores: Chemical Aspects. Annu. Rev. Plant Biol. 2012, 63, 431-450. [CrossRef]

95. War, A.R.; Paulraj, M.G.; Ahmad, T.; Buhroo, A.A.; Hussain, B.; Ignacimuthu, S.; Sharma, H.C. Mechanisms of plant defense against insect herbivores. Plant Signal. Behav. 2012, 7, 1306-1320. [CrossRef] [PubMed]

96. Huitu, O.; Forbes, K.M.; Helander, M.; Julkunen-Tiitto, R.; Lambin, X.; Saikkonen, K.; Stuart, P.; Sulkama, S.; Hartley, S. Silicon, endophytes and secondary metabolites as grass defenses against mammalian herbivores. Front. Plant Sci. 2014, 5, 478. [CrossRef]

97. Isah, T. Stress and defense responses in plant secondary metabolites production. Biol. Res. 2019, 52, 39. [CrossRef]

98. Niemeyer, H.M. Hydroxamic acids (4-hydroxy-1,4-benzoxazin-3-ones), defence chemicals in the gramineae. Phytochemistry 1988, 27, 3349-3358. [CrossRef]

99. Bernays, E.A.; Driver, G.C.; Bilgener, M. Herbivores and plant tannins. Adv. Ecol. Res. 1989, 19, $263-302$.

100. Jones, D.A. Cyanogenesis in animal-plant interactions. Ciba Found. Symp. 1988, 140, 151-170. [PubMed]

101. Taiz, L.; Zeiger, E. Plant Physiology, 5th ed.; Sinauer Associates, Inc.: Sunderland, MA, USA, 2010.

102. Nabity, P.D.; Zavala, J.A.; Delucia, E.H. Herbivore induction of jasmonic acid and chemical defences reduce photosynthesis in Nicotiana attenuata. J. Exp. Bot. 2013, 64, 685-694. [CrossRef]

103. Olivoto, T.; Nardino, M.; Carvalho, I.R.; Follmann, D.N.; Szareski, V.J.; Ferrari, M.; de Pelegrin, A.J.; de Souza, V.Q. Plant secondary metabolites and its dynamical systems of induction in response to environmental factors: A review. Afr. J. Agric. Res. 2017, 12, 71-84.

104. Veitch, G.E.; Boyer, A.; Ley, S.V. The azadirachtin story. Angew. Chem. Int. Ed. 2008, 47, 9402-9429. [CrossRef] 
105. Adamczyk, B.; Kitunen, V.; Smolander, A. Response of soil C and N transformations to condensed tannins and different organic N-condensed tannin complexes. Appl. Soil Ecol. 2013, 64, 163-170. [CrossRef]

106. Chen, Q.; Lu, X.; Guo, X.; Liu, J.; Liu, Y.; Guo, Q.; Tang, Z. The specific responses to mechanical wound in leaves and roots of Catharanthus roseus seedlings by metabolomics. J. Plant Interact. 2018, 13, 450-460. [CrossRef]

107. Hollingsworth, P.M.; Forrest, L.L.; Spouge, J.L.; Hajibabaei, M.; Ratnasingham, S.; van der Bank, M.; Chase, M.W.; Cowan, R.S.; Erickson, D.L.; Fazekas, A.J.; et al. A DNA barcode for land plants. Proc. Natl. Acad. Sci. USA 2009, 106, $12794-12797$.

108. Taberlet, P.; Gielly, L.; Pautou, G.; Bouvet, J. Universal primers for amplification of three non-coding regions of chloroplast DNA. Plant Mol. Biol. 1991, 17, 1105-1109. [CrossRef] 